$$
x
$$




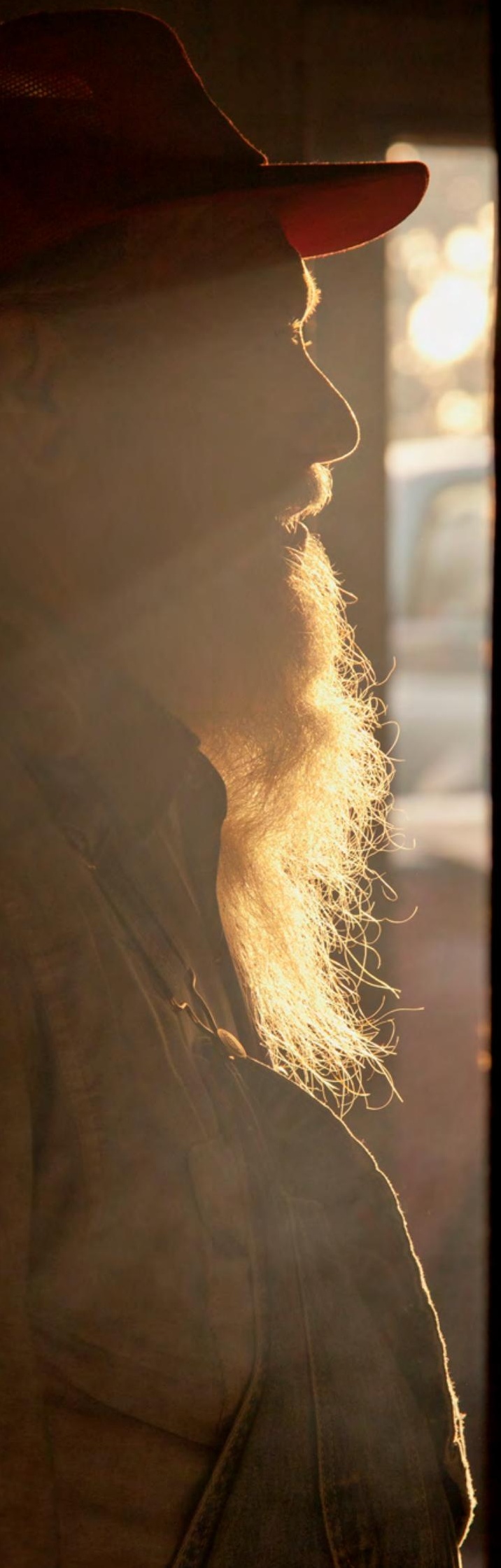


NOTESANDRECIPES FROM-A.

\title{
SOUTHERN ODYSSEY
}

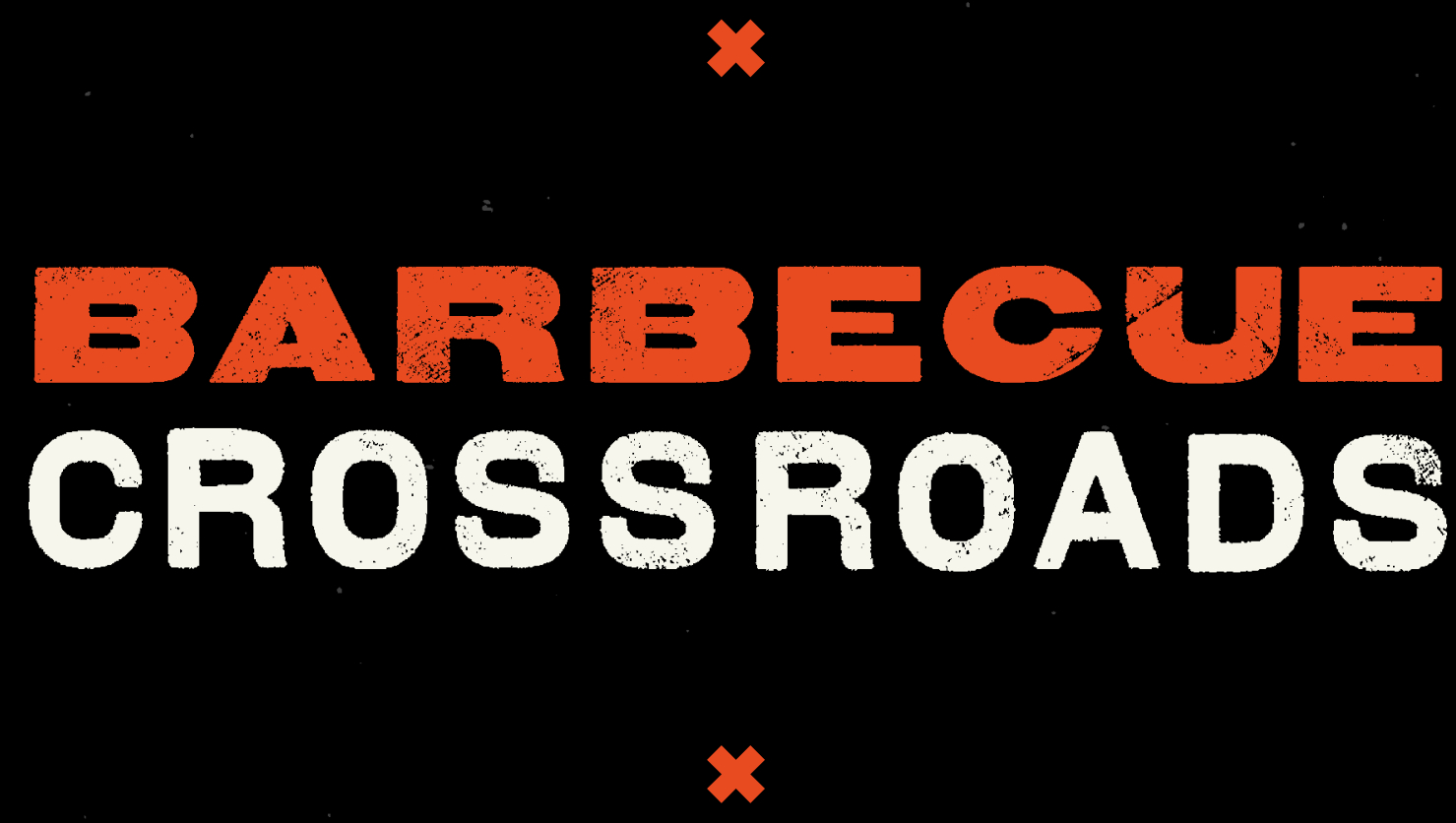

ROBB WALSH

\author{
PHOTOGRAPHS B Y \\ O. RUFUS LOVETT
}

UNIVERSITY OF TEXAS PRESS 4V AUSTIN 
Kund 250

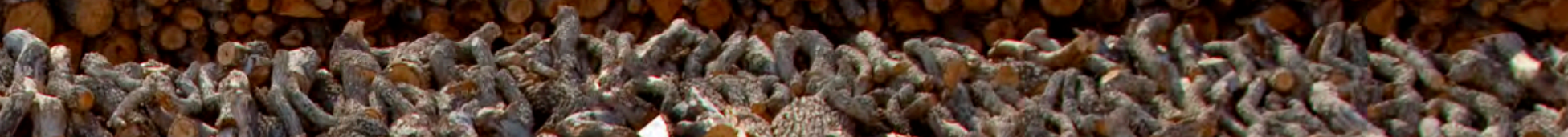

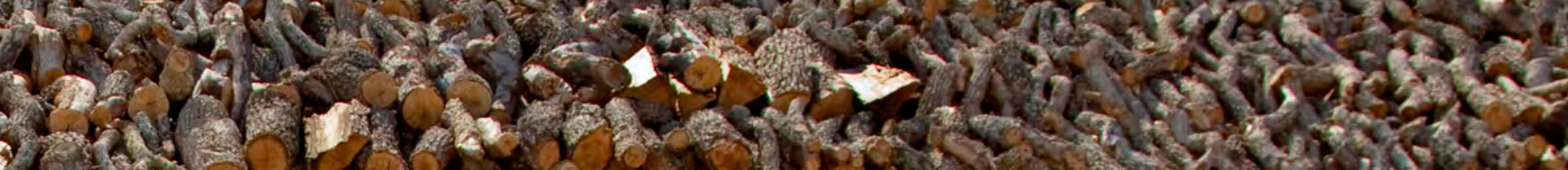

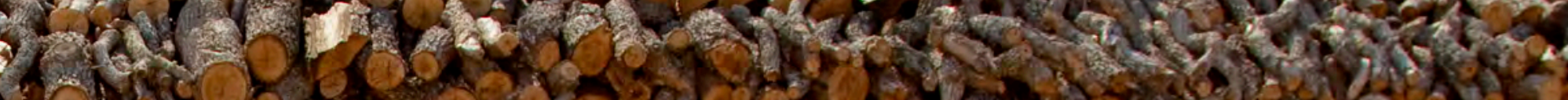

\section{TIN 1001 .} (20.)
and 12
(N)
incing
Nond 10
$+10 \times 2 \times 19$
$009 \times 1=020$
8 -
o. 14

W.1Wx

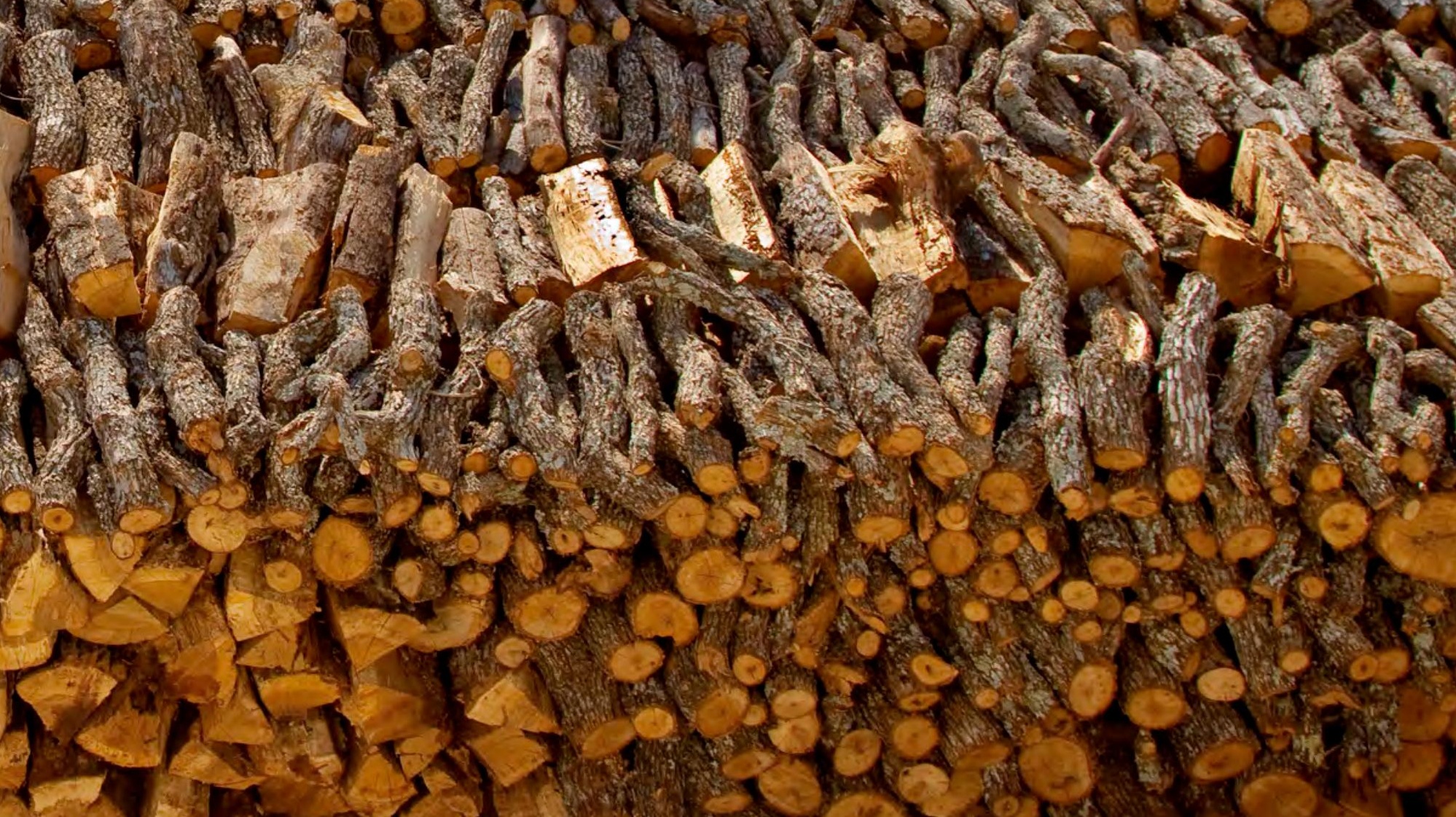


Publication of this book was aided by the generous support of

Michele and Brad Moore

Ellen and Edward Randall

Richard and Martha Rorschach

Text copyright $@ 2013$ by Robb Walsh

Photographs copyright (c) 2013 by O. Rufus Lovett

All rights reserved

Printed in China

First edition, 2013

Requests for permission to reproduce material

from this work should be sent to:

Permissions

University of Texas Press

P.O. Box 7819

Austin, TX 78713-7819

http://utpress.utexas.edu/about/book-permissions

The paper used in this book meets the minimum requirements of ANSI/NISO Z39.48-1992 (R1997) (Permanence of Paper). @)

Design by Lindsay Starr

LIBRARY OF CONGRESS CATALOGING-IN-PUBLICATION DATA

Walsh, Robb, 1952-

Barbecue crossroads : notes and recipes from a southern odyssey / By Robb Walsh ;

Photographs by O. Rufus Lovett. — First edition.

p. $\mathrm{cm}$.

Includes bibliographical references and index.

ISBN 978-0-292-73932-1 (cloth : alk. paper)

1. Barbecuing-Southern States. I. Lovett, O. Rufus, 1952- photographer. II. Title.

TX840.B3W35 2012

$641.7^{\prime} 60975-\mathrm{dc} 23$

2012035824

doi:10.756o/739321

Frontis: Community barbecue crew member Bubba Roese at the Sons of Hermann Lodge in Washington, Texas

Pages iv-v: The woodpile at Smitty's Market in Lockhart, Texas.

Post oak is seasoned for two years before it's burned. 
Dedicated to Richard Walsh and Opal Rufus Lovett 


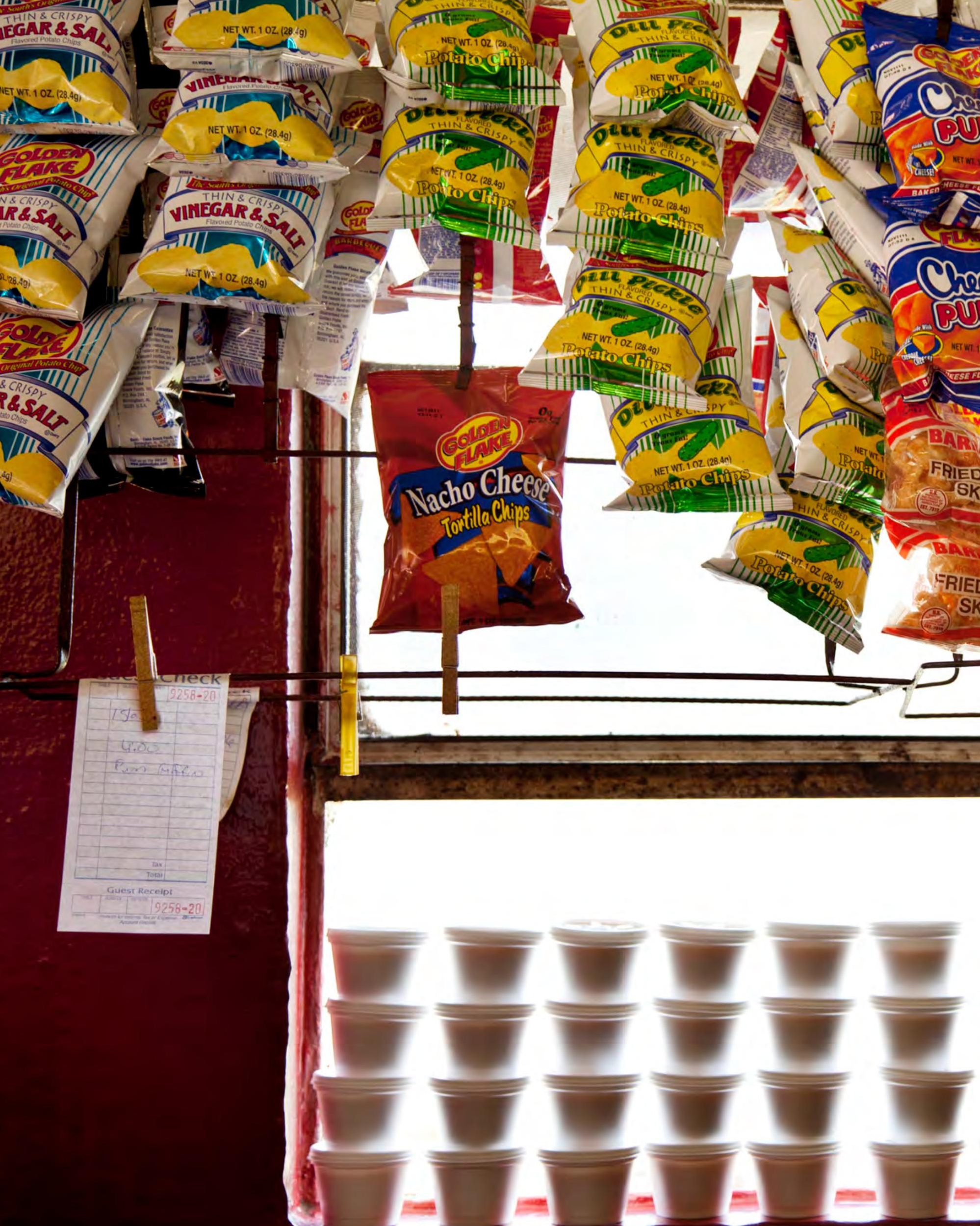

